\title{
Pengaruh Ukuran Perusahaan, Corporate Social Responsibility, Capital Intensity, Leverage dan Komisaris Independen terhadap Agresivitas Pajak Penghasilan Wajib Pajak Badan pada Perusahaan Industri Konsumsi di Bursa Efek Indonesia Tahun 2015-2017
}

\author{
Putu Riska Junensie*, A. A. Ayu Erna Trisnadewi dan I Gusti Ayu Intan Saputra Rini \\ Jurusan Akuntansi, Fakultas Ekonomi, Universitas Warmadewa, Denpasar, Bali-Indonesia \\ *riskaj34@gmail.com
}

How to cite (in APA style):

Junensie, P. R., Trisnadewi, A. A. A. E., \& Rini, I. G. A. I. S. (2020). Pengaruh Ukuran Perusahaan, Corporate Social Responsibility, Capital Intensity, Leverage dan Komisaris Independen terhadap Agresivitas Pajak Penghasilan Wajib Pajak Badan pada Perusahaan Industri Konsumsi di Bursa Efek Indonesia Tahun 2015-2017. Wacana Ekonomi (Jurnal Ekonomi, Bisnis dan Akuntansi). 19(1), pp.67-77. http://dx.doi.org/10.22225/we.19.1.1600.67-77

\begin{abstract}
This research was conducted to analyze the effect of company size, corporate social responsibility (CSR), capital intensity, leverage, and independent commissioners on tax aggressiveness. This research uses quantitative data and the source of the data is a type of secondary data obtained from annual reports or annual reports of consumption industry companies listing on the IDX during 2015 to 2017 obtained on the IDX's official website www.idx.co.id and other relevant sources such as the Indonesian Capital Market Directory (ICMD). The population is the consumption industry companies listed on the Stock Exchange in 2015 and 2017. The number of were 24 companies taken using purposive sampling techniques. The analysis technique is a quantitative analysis using the classic assumption test which includes normality test, autocorrelation test, heterokedasticity test and multicollinearity test. The next analysis technique is the F test, regression coefficient test, $t$ test, and the determinant coefficient test. Based on the results of the analysis, the regression coefficient equation is obtained $Y=-45,230+0,000 X 1+165,299 X 2+4,204 X 3-30,658 X 4+45,620 X 5+e$. Based on the t test, the results of corporate social responsibility (CSR) and capital intensity have a positive effect on the aggressiveness of income taxes, while company size, leverage and independent commissioners have no effect on the aggressiveness of income tax.
\end{abstract}

Keywords: Aggressiveness of income tax; capital intensity; corporate social responsibility (CSR); independent commissioner; leverage; company size

Abstrak

Penelitian ini dilakukan untuk menganalisis pengaruh ukuran perusahaan, corporate social responsibility (CSR), capital intensity, leverage, dan komisaris independen terhadap agresivitas pajak. Penelitian ini menggunakan data kuantitatif serta sumber data yang digunakan merupakan jenis data sekunder yang diperoleh dari laporan tahunan atau annual report perusahaan industri konsumsi yang listing di BEI selama tahun 2015 sampai dengan tahun 2017 yang diperoleh dalam situs resmi BEI www.idx.co.id serta sumber lain yang relevan seperti Indonesian Capital Market Directory (ICMD). Populasi yang digunakan adalah perusahaan industry konsumsi yang terdaftar di BEI pada tahun 2015 dan 2017. Jumlah sampel yang digunakan sebanyak 24 perusahaan yang diambil menggunakan teknik purposive sampling. Teknik analisis yang digunakan adalah analisis kuantitatif dengan menggunakan uji asumsi klasik yang meliputi uji normalitas, ui autokorelasi, uji heterokedastisitas dan uji multikolonieritas. Teknik analisis selanjutnya yaitu uji F, uji koefisien regresi, uji t, dan uji koefisien determinan. Berdasarkan hasil analisis tersebut maka diperoleh persamaan koefisien regresi adalah $\mathrm{Y}=-45,230+0,000 \mathrm{X} 1+165,299 \mathrm{X} 2+4,204 \mathrm{X} 3-30,658 \mathrm{X} 4+45,620 \mathrm{X} 5+\mathrm{e}$. Berdasarkan uji t didapatkan hasil corporate social responsibility (CSR) dan capital intensity berpengaruh positif terhadap agresivitas pajak penghasilan, sedangkan ukuran perusahaan, leverage dan komisaris independen tidak berpengaruh terhadap agresivitas pajak penghasilan.

Kata Kunci: Agresivitas pajak penghasilan; capital intensity; corporate social responsibility (CSR); komisaris independen; leverage; ukuran perusahaan

\section{PENDAHULUAN}

Pendapatan negara memegang peranan penting bagi kesejahteraan rakyat. Penerimaan negara yang paling potensial bersumber dari peneriman pajak. Menurut Badan Pusat Statistik Republik Indonesia (2017), pada 2017 realisasi penerimaan negara sebesar Rp 1.737.629,4 miliar sebanyak 
60\% (sebesar Rp 1.495.893,80) berasal dari penerimaan perpajakan. Penerimaan perpajakan yang didapat tersebut sebesar $49,96 \%$ (sebesar $\mathrm{Rp} 784.726,90$ ) berasal dari pajak penghasilan seperti yang terlihat dalam Tabel 1 berikut:

Table 1

Penerimaan Negara Republik Indonesia Tahun 2017

\begin{tabular}{|c|c|}
\hline Sumber Penerimaan & 2017 \\
\hline Penerimaan Dalam Negeri & $1,736,256.70$ \\
\hline Penerimaan Perpajakan & $1,495,893.80$ \\
\hline Pajak Dalam Negeri & $1,461,818.70$ \\
\hline Pajak Penghasilan & $784,726.90$ \\
\hline Penerimaan Bukan Pajak & $240,362.90$ \\
\hline Hibah & $1,372.70$ \\
\hline Jumlah & $1,737,629.40$ \\
\hline
\end{tabular}

Sumber: Badan Pusat Statistik Republik Indonesia Tahun 2017

Perusahaan termasuk dalam salah satu kriteria badan, dimana menjadi salah satu penyumbang terbesar penerimaan pajak (Rina, 2016). Setiap perusahaan didirikan dengan struktur dan tujuan yang berbeda. Meningkatkan nilai adalah tujuan utama yang ingin dicapai setiap perusahaan. Peningkatan atau penurunan nilai perusahaan dapat diukur dengan kinerja keuangan yang dilihat dalam laporan keuangan. Salah satu indikator penting dalam laporan keuangan yang digunakan untuk mengetahui peningkatan nilai perusahaan adalah laba.

Perusahaan sebagai salah satu wajib pajak mempunyai kewajiban untuk membayar pajak. Semakin besar pajak yang dibayarkan perusahaan, maka pendapatan negara semakin banyak. Tujuan pemerintah untuk memaksimalkan penerimaan di sektor pajak bertentangan dengan tujuan perusahaan sebagai wajib pajak, dimana perusahaan berusaha untuk mengefisiensikan beban pajaknya sehingga memperoleh keuntungan yang lebih besar dalam rangka mensejahterakan pemilik dan melanjutkan kelangsungan hidup perusahaannya.

Bagi perusahaan, pajak dianggap sebagai biaya atau beban yang akan mengurangi keuntungan perusahaan. Hal itu menyebabkan banyak perusahaan yang berusaha mencari cara untuk mengurangi biaya pajak yang harus dibayar dengan melakukan perencanaan maupun pengaturan terhadap pajak yang harus dibayar (Mustika, Ratnawati, \& Silfi, 2017). Penghindaran pajak dapat didefinisikan secara luas bukan untuk meningkatkan laba saja, diharapkan juga mampu meningkatkan nilai perusahaan.

Agresivitas Pajak Perusahaan yaitu keinginan perusahaan untuk meminimalkan beban pajak yang dibayar dengan cara yang legal, illegal, maupun kedua-duanya. Agresivitas pajak perusahaan juga dinilai dari seberapa besar perusahaan tersebut mengambil langkah penghindaran pajak dengan memanfaatkan celah-celah yang ada dalam peraturan perpajakan. Perusahaan yang melakukan pengungkapan corporate social responsibility tentunya memberikan dampak yang positif bagi perusahaannya, karena dianggap telah berkontribusi kepada sosial dan lingkungan, serta memberikan anggapan bahwa perusahaan tersebut tidak hanya menggunakan sumber daya saja. Pengaruh perusahaan dalam membayar pajak juga dipengaruhi oleh ukuran perusahaan. Semakin besar aset yang dimiliki perusahaan maka semakin besar ukuran perusahaan. Faktor lain yang dapat mempengaruhi agresivitas pajak perusahaan adalah leverage. Leverage atau solvabilitas merupakan suatu ukuran seberapa besar aset yang dimiliki perusahaan dibiayai oleh utang. Leverage menunjukkan penggunaan utang untuk membiayai investasi.

Selain hal diatas, hal yang dapat mempengaruhi perusahaan dalam besar kecilnya membayar pajak antara lain capital intensity dan komisaris independen, dimana capital intensity atau rasio intensitas modal adalah aktivitas investasi perusahaan yang dikaitkan dengan investasi aset tetap dan persediaan. Sedangkan komisaris independen merupakan dewan komisaris yang bersifat mandiri, tidak terpengaruh dengan kondisi perusahaan. Namun, komisaris independen tidak dapat memberikan keputusan untuk kepentingan perusahaan, hanya untuk memberikan saran dan pendapat tentang akibat yang akan ditanggung perusahaan atas tindakanya. Penelitian ini termotivasi dari isu-isu yang beredar mengenai perpajakan serta diikuti oleh fenomena dimana, pajak penghasilan turut serta menjadi penambah ataupun pengurang dalam penerimaan perpajakan.

Pada penelitian sebelumnya, hasil penelitian (Nugraha \& Meiranto, 2015) menemukan bahwa CSR dan pengaruh signifikan terhadap agresivitas pajak. Sedangkan ukuran, profitabilitas dan 
intensitas modal tidak secara signifikan mempengaruhi agresivitas pajak. Hasil yang sama juga ditemukan oleh (Ayem \& Setyadi, 2019), dimana pada penelitiannya yang dilakukan pada Perusahaan Perbankan Yang Terdaftar di BEI Periode Tahun 2013-2017 mengungkapkan bahwa profitabilitas, ukuran perusahaan, komite audit dan intensitas modal memiliki berpengaruh positif dan signifikan terhadap agresivitas pajak keduanya secara parsial dan simultan.

Berdasarkan latar belakang tersebut maka penelitian ini dilakukan untuk menganalisis pengaruh ukuran perusahaan terhadap agresivitas pajak penghasilan wajib pajak badan pada perusahaan industri konsumsi di Bursa Efek Indonesia (BEI), pengaruh corporate social responsibility (CSR) terhadap agresivitas pajak penghasilan wajib pajak badan pada perusahaan industri konsumsi di Bursa Efek Indonesia, pengaruh capital intensity terhadap agresivitas pajak penghasilan wajib pajak badan pada perusahaan industri konsumsi di Bursa Efek Indonesia (BEI) pengaruh leverage terhadap agresivitas pajak penghasilan wajib pajak badan pada perusahaan industri konsumsi di Bursa Efek Indonesia (BEI) dan pengaruh komisaris independen terhadap agresivitas pajak penghasilan wajib pajak badan pada perusahaan industri konsumsi di Bursa Efek Indonesia (BEI).

\section{TINJAUAN PUSTAKA}

\section{Ukuran Perusahaan}

Ukuran perusahaan sebagai skala atau nilai yang dapat mengklasifikasikan suatu perusahaan kedalam kategori besar atau kecil menurut berbagai cara seperti total aktiva atau total asset perusahaan, nilai pasar saham, rata - rata tingkat penjualan dan jumlah penjualan (Cahyono, Andini, \& Raharjo, 2016). Ukuran perusahaan dianggap mampu mempengaruhi nilai perusahaan. Semakin besar ukuran atau skala perusahaan maka akan semakin mudah pula perusahaan memperoleh sumber pendanaan baik yang bersifat internal maupun eksternal. Ukuran perusahaan merupakan cerminan total dari aset yang dimiliki suatu perusahan (Rudangga \& Sudiarta, 2016).

Ukuran perusahaan dinilai besar kecilnya perusahaan berdasarkan nilai equity, nilai penjualan, dan nilai aktiva pada perusahaan industri konsumsi yang terdaftar di BEI. Ukuran perusahaan dapat diproksi dengan log natural total aset, sehingga dapat dihitung dengan rumus sebagai berikut:

Size $=$ Ln (total aset)

\section{Corporate Social Responsibility (CSR)}

Corporate Social Responsibility (CSR) adalah komitmen perusahaan atau dunia bisnis untuk berkontribusi dalam pengembangan ekonomi yang berkelanjutan dengan memperhatikan tanggung jawab sosial perusahaan dan menitikberatkan pada keseimbangan antara perhatian terhadap aspek ekonomi, sosial dan lingkungan (Untung, 2009). Pendapat lainnya mengungkapkan Corporate Social Responsibility (CSR) adalah komitmen perusahaan untuk berkontribusi dalam pengembangan ekonomi yang berkelanjutan dengan memperhatikan tanggung jawab sosial perusahaan dan menitikberatkan pada keseimbangan antara perhatian terhadap aspek ekonomis, sosial dan lingkungan (Hidayati \& Saifi, 2019).

Pengungkapan Corporate Social Responsibility terdapat dalam laporan tanggung jawab sosial perusahaan, laporan sumber daya manusia, laporan kesehatan dan keselamatan kerja. Corporate Social Responsibility diproksikan dengan pengungkapan Corporate Social Responsibility yang diukur dengan menggunakan check list yang mengacu pada indikator pengungkapan yang digunakan secara umum di dunia yaitu Global Reporting Initiative (GRI). Adapun cara menghitung CSRI adalah sebagai berikut:

$$
\underline{\mathrm{CSRIj}}=\underset{\mathrm{nj}}{\sum \mathrm{XIj}}
$$

CSR1j : indeks luas pengungkapan tanggung jawab sosial dan lingkungan perusahaan $\mathrm{j}$.

$\sum X i j \quad$ : nilai 1 jika item i diungkapkan; nilai 0 jika item i tidak diungkapkan.

nj $\quad$ : jumlah item perusahaan $\mathrm{j}, \mathrm{nj} \leq 91$

\section{Capital Intensity}

Capital intensity atau intensitas modal adalah rasio antara fixed asset (seperti peralatan, mesin 
dan berbagai properti) terhadap total aset, dimana rasio ini menggambarkan besar aset perusahaan yang diinvestasikan dalam bentuk asset tetap yang dibutuhkan perusahaan untuk beroperasi. Capital intensity berhubungan dengan investasi perusahaan dalam aset tetap. Semakin tinggi capital intensity suatu perusahaan, maka beban depresiasi aset tetap semakin meningkat Hal tersebut akan menyebabkan laba perusahaan yang semakin menurun, sehingga pajak terutang perusahaan juga akan semakin menurun. Jika laba perusahaan menurun, maka perusahaan tersebut memiliki ETR yang rendah yang mengindikasikan tingkat penghindaran pajak yang makin tinggi (Dwiyanti \& Jati, 2019).

Capital intensity dapat didefinisikan dengan bagaimana perusahaan berkorban mengeluarkan dana untuk aktivitas operasi dan pendanaan aktiva guna memperoleh keuntungan perusahaan. Pengukuran capital intensity dihitung dengan rumus:

\section{$\underline{\mathrm{CAPT}}=$ Total aset tetap bersih}

Total aset

\section{Leverage}

Leverage atau yang bisa juga disebut dengan rasio solvabilitas merupakan suatu rasio yang digunakan untuk mengukur sejauh mana aktiva perusahaan dibiayai dengan utang. Artinya berapa besar beban utang yang ditanggung perusahaan dibandingkan dengan aktivanya. Leverage dalam arti luas digunakan untuk mengukur kemampuan perusahaan untuk membayar seluruh kewajibannya, baik jangka pendek maupun jangka panjang apabila perusahaan dibubarkan (likuidasi) (Kasmir, 2016).

Leverage diukur dengan Debt to Total Asset Ratio (Debt Rasio), dapat dibandingkan antara hutang dengan total aktiva perusahaan industry konsumsi di BEI. Leverage dihitung dengan rumus berikut ini :

$$
\underline{\text { Leverage }}=\text { Total utang }
$$

Total aset

\section{Komisaris Independen}

Definisi komisaris independen menurut (Komite Nasional Kebijakan Governance, 2006) adalah Komisaris independen adalah anggota dewan komisaris yang tidak terafiliasi dengan manajemen, anggota dewan komisaris lainnya dan pemegang saham pengendali, serta bebas dari hubungan bisnis atau hubungan lainnya yang dapat mempengaruhi kemampuannya untuk bertindak independen atau bertindak semata-mata demi kepentingan perusahaan.

Komisaris independen merupakan dewan komisaris yang bersifat mandiri, tidak terpengaruh dengan kondisi perusahaan. Namun, komisaris independen tidak dapat memberikan keputusan untuk kepentingan perusahaan, hanya untuk memberikan saran dan pendapat tentang akibat yang akan ditanggung perusahaan atas tindakanya. Komisaris independen dapat dirumuskan :

\section{$\underline{\mathrm{KI}}=$ Komisaris independen}

Total komisaris

\section{Agresivitas Pajak}

Tindakan agresivitas pajak, yang mana tindakan tersebut dilakukan dengan cara meminimalisasi jumlah kena pajak yang diperoleh perusahaan, merupakan hal yang sering terjadi pada perusahaan-perusahaan besar saat ini. Hal ini tidak sesuai dengan aturan yang telah berlaku baik di masyarakat maupun dalam pemerintahan. Pengurangan dasar pengenaan pajak biasanya diberikan dalam bentuk bebagai macam biaya yang dapat dikurangkan dari pendapatan kena pajak. Pengurangan tariff pajak biasanya diberikan untuk jenis perusahaan tertentu atau jenis usaha tertentu (Suandy, 2004).

\section{Hipotesis}

\section{Pengaruh Ukuran Perusahaan terhadap Agresivitas Pajak Penghasilan}

Ukuran perusahaan dapat diartikan sebagai suatu skala dimana dapat diklasifikasikan besar kecil perusahaan dengan berbagai cara antara lain dinyatakan dalam total asset, nilai pasar saham, dan lain-lain. Semakin besar ukuran perusahaan tersebut pasti akan semakin berusaha untuk melakukan penghindaran atau agresivitas pajak. Oleh karena itu, hipotesis dalam penelitian ini adalah 
H1 : ukuran perusahaan berpengaruh negatif terhadap agresivitas pajak penghasilan wajib pajak badan pada perusahaan industri konsumsi di BEI.

\section{Pengaruh Corporate Social Responsibility (CSR) terhadap Agresivitas Pajak Penghasilan}

Tingkat kesadaran perusahaan untuk menerapkan CSR dalam operasinya berbeda antara yang satu dengan yang lainnya. CSR merupakan kontribusi perusahaan bagi masyarakat dalam usaha peningkatan kualitas kehidupan. Dalam penelitian yang dilakukan oleh (Nugraha \& Meiranto, 2015) menunjukkan bahwa Corporate Social Responsibility (CSR) berpengaruh negatif terhadap agresivitas pajak. Berdasarkan landasan teori dan hasil penelitian sebelumnya maka hipotesis yang diajukan adalah:

H2 : Corporate Social Responsibility (CSR) berpengaruh negatif terhadap agresivitas pajak penghasilan wajib pajak badan pada perusahaan industri konsumsi di BEI.

Pengaruh Capital Intensity terhadap Agresivitas Pajak Penghasilan

Capital Intensity dapat didefinisikan dengan bagaimana perusahaan berkorban mengeluarkan dana untuk aktivitas operasi dan pendanaan aktiva guna memperoleh keuntungan perusahaan. Dari penelitian yang dilakukan (Nugraha \& Meiranto, 2015) diperoleh hasil bawah Capital Intensity berpengaruh negatif terhadap agresivitas pajak penghasilan. Sehingga hipotesis dalam penelitian ini adalah

H3 : Capital Intensity berpengaruh negatif terhadap agresivitas pajak penghasilan wajib pajak badan pada perusahaan industri konsumsi di BEI.

Pengaruh Leverage terhadap Agresivitas Pajak Penghasilan

Leverage adalah kemampuan perusahaan menggunakan utang untuk membiayai investasi perusahaannya (Fadli, Ratnawati, \& Kurnia, 2016). Selain itu, dari penelitian yang dilakukan oleh (Fadli et al., 2016) diperoleh hasil bahwa Leverage berpengaruh positif terhadap agresivitas pajak penghasilan. Berdasarkan landasan teori dan hasil penelitian sebelumnya maka hipotesis yang diajukan adalah:

H4 : Leverage berpengaruh positif terhadap agresivitas pajak penghasilan wajib pajak badan pada perusahaan industri konsumsi di BEI.

Pengaruh Komisaris Independen terhadap Agresivitas Pajak Penghasilan

Komisaris Independen melakukan pengawasan dengan baik dan mengarahkan perusahaan berdasarkan pada aturan yang telah ditetapkan. Hasil penelitian yang dilakukan oleh (Fadli et al., 2016) membuktikan bahwa komisaris independen berpengaruh negatif terhadap agresivitas pajak penghasilan. Berdasarkan landasan teori dan hasil penelitian sebelumnya maka hipotesis yang diajukan adalah:

H5 :komisaris independen berpengaruh negatif terhadap agresivitas pajak penghasilan wajib pajak badan pada perusahaan industri konsumsi di BEI.

\section{METODE}

Penelitian ini menggunakan data kuantitatif, dimana sumber data yang digunakan merupakan jenis data sekunder dari laporan tahunan atau annual report perusahaan industri konsumsi yang listing di BEI selama tahun 2015 sampai dengan tahun 2017. Data diperoleh dalam situs resmi BEI www.idx.co.id serta sumber lain yang relevan seperti Indonesian Capital Market Directory (ICMD). Penelitian dilakukan di Kantor Perwakilan Bursa Efek Indonesia Denpasar yang berlokasi di Jl. Cok Agung Tresno No. 163, Renon, Denpasar Timur, Kota Denpasar, Bali. Objek dalam penelitian ini adalah ukuran perusahaan, corporate social responsibility, capital intensity, leverage dan komisaris independen. Keseluruhan objek akan diteliti di Perusahaan Industri Konsumsi pada PT Bursa Efek Indonesia. Populasi dalam penelitian ini berjumlah 43 perusahaan dengan Teknik pemilihan sampel yang digunakan adalah purposive sampling, yaitu dengan mengambil sampel yang telah ditentukan sebelumnya berdasarkan maksud dan tujuan penelitian dengan criteria yang telah ditentukan.

Variabel dalam penelitian ini terdiri dari variabel dependen dan variabel independen. Variabel dependen yang digunakan yaitu agresivitas pajak penghasilan $(\mathrm{Y})$, sedangkan variabel independen adalah (X1) Ukuran Perusahaan, (X2) Corporate Social Responsibility, (X3) Capital Intensity, (X4) 
Leverage dan (X5) Komisaris Independen. Teknik analisis data yang digunakan dalam penelitian ini adalah analisis kuantitatif dengan menggunakan uji asumsi klasik yang meliputi uji normalitas, ui autokorelasi, uji heterokedastisitas dan uji multikolonieritas. Teknik analisis selanjutnya yaitu uji $\mathrm{F}$, uji koefisien regresi, uji t, dan uji koefisien determinan

\section{HASIL DAN PEMBAHASAN}

Data yang digunakan dalam penelitian ini merupakan jenis data sekunder yang diperoleh dari laporan tahunan atau annual report perusahaan industri konsumsi yang listing di BEI selama tahun 2015 sampai dengan tahun 2017. Terdapat 24 perusahaan yang digunakan sebagai sampel penelitian, dengan perincian data sebagai berikut:

Table 2

Data Perhitungan Variabel

\begin{tabular}{cc}
\hline Kriteria Sampel & Jumlah \\
\hline Jumlah perusahaan industri konsumsi yang terdaftar di BEI tahun 2015-2017 & 43 \\
Perusahaan industri konsumsi yang tidak mempublikasikan laporan tahunan & $(13)$ \\
(annual report) dan laporan keuangan dari tahun 2015-2017 & 0 \\
Laporan keuangan yang menggunakan mata uang asing & $(6)$ \\
Jumlah perusahaan yang mengalami kerugian & 24 \\
Jumlah perusahaan yang dijadikan sampel & \\
\hline
\end{tabular}

Sumber : Data diolah, 2019

\section{Statistik Deskriptif}

Analisis statistik deskriptif berguna untuk menjelaskan variabel-variabel dalam penelitian, meliputi variabel dependen yaitu agresivitas pajak penghasilan, dan variabel independen yaitu ukuran perusahaan, Corporate Social Responsibility (CSR), capital intensity, leverage dan komisaris independen seperti yang ditunjukkan pada Tabel 3 berikut :

Table 3

Hasil Statistik Deskriptif

\begin{tabular}{cccccc}
\hline & $\mathrm{N}$ & Minimum & Maximum & Mean & Std. Deviation \\
\hline Ukuran Perusahaan & 24 & 1141,24 & 383574,40 & 17217,320 & 78033,966 \\
CSR & 24 & 0,264 & 0,648 & 0,438 & 0,079 \\
Capital Intensity & 24 & 0,000 & 26,197 & 1,096 & 5,347 \\
Leverage & 24 & 0,077 & 1,516 & 0,439 & 0,310 \\
Komisaris Independen & 24 & 0,333 & 0,800 & 0,377 & 0,100 \\
Agresivitas Pajak & 24 & 0,004 & 113,066 & 37,373 & 28,310 \\
Valid N (listwise) & 24 & & & & \\
\hline
\end{tabular}

Sumber : Data diolah, 2019

\section{Uji Normalitas}

Uji normalitas bertujuan untuk menguji apakah dalam regresi, variabel pengganggu atau residual memiliki distribusi normal (Ghozali, 2016). Uji normalitas yang digunakan adalah uji Kolmogorov-Smirnov Test. Uji ini digunakan untuk uji statistik apakah data terdistribusi normal atau tidak. Uji Kolmogorov-Smirnov Test dengan ketentuan yaitu, jika nilai signifikansi yang dihasilkan > 0,05 maka data distribusi data normal. Uji normalitas dapat dilihat pada tabel berikut :

Table 4

Hasil Uji Normalitas

\begin{tabular}{ccc}
\hline & & Unstandardized Residual \\
\hline \multirow{2}{*}{$\mathrm{N}$} & Mean & 24 \\
Normal Parameters(a,b) & Std. Deviation & 0,0000000 \\
Most Extreme Differences & Absolute & 18,29040267 \\
& Positive & 0,200 \\
& Negative & 0,200 \\
Kolmogorov-Smirnov Z & & $-0,126$ \\
Asymp. Sig. (2-tailed) & Sig. & 0,979 \\
Monte Carlo Sig. (2-tailed) & 0,293 \\
\end{tabular}


a. Test distribution is Normal.

b. Calculated from data.

c. Based on 10000 sampled tables with starting seed 2000000 .

Sumber : Data diolah, 2019

Hasil uji normalitas dengan menggunakan kolmogorov-smirnov testnilai Asymp. Sig. (2tailed) sebesar 0,262 dimana hasil tersebut lebih besar dari 0,05 sehingga dapat disimpulkan bahwa data yang digunakan dalam penelitian ini adalah data distribusi normal.

\section{Uji Autokorelasi}

Uji autokorelasi bertujuan untuk menguji apakah dalam model regresi liner ada korelasi antara kesalahan pengganggu pada periode tertentu dengan kesalahan pengganggu pada period sebelumnya (Ghozali, 2018). Untuk mendeteksi ada atau tidaknya autokorelasi maka digunakan run test. Run test digunakan sebagai bagian dari statistik non-parametrik dapat pula digunakan untuk menguji apakah antar residual terdapat korelasi yang tinggi. Hasil uji run test dapat dilihat pada Tabel 5 berikut:

Tabel 5

Hasil Uji Autokorelasi

\begin{tabular}{cc}
\hline & Unstandardized Residual \\
\hline Test Value(a) & $-1,48721$ \\
Cases $<$ Test Value & 12 \\
Cases $>=$ Test Value & 12 \\
Total Cases & 24 \\
Number of Runs & 13 \\
Z & 0,000 \\
Asymp. Sig. (2-tailed) & 1,000 \\
\hline
\end{tabular}

a. Median

Sumber : Data diolah, 2019

Berdasarkan hasil run test didapatkan nilai asymp. Sig. (2-tailed) sebesar 1,000 >0,05, yang berarti data yang digunakan cukup random sehingga tidak terdapat masalah autokorelasi pada data yang diuji.

\section{Uji Heteroskedastisitas}

Uji Heteroskedastisitas bertujuan menguji apakah dalam model regresi terjadi ketidaksamaan variance dari residual satu pengamatan yang lain. Uji heterokedastisitas dalam penelitian ini dilakukan uji glejser yang dapat dilihat sebagai berikut:

Tabel 6

Hasil Uji heterokedastisitas

\begin{tabular}{ccccccc}
\hline \multirow{2}{*}{ Model } & & \multicolumn{2}{c}{ Unstandardized Coefficients } & Standardized & Coefficients \\
& & $\mathrm{B}$ & Std. Error & Beta & Sig. \\
\hline 1 & (Constant) & $-36,491$ & 23,117 & & $-1,579$ & 0,132 \\
& Ukuran Perusahaan & $-3,190$ & 0,000 & $-0,185$ & $-0,938$ & 0,360 \\
& CSR & 87,324 & 41,051 & 0,513 & 2,127 & 0,057 \\
& Capital Intensity & 0,130 & 0,576 & 0,052 & 0,225 & 0,824 \\
& Leverage & $-15,164$ & 9,526 & $-0,351$ & $-1,592$ & 0,129 \\
& Komisaris Independen & 46,245 & 29,617 & 0,346 & 1,561 & 0,136 \\
\hline
\end{tabular}

a. Dependent Variable: Abs_RES

Sumber : Data diolah, 2019

Berdasarkan Tabel 6, terlihat bahwa signifikansi semua variabel $>0,05$ yang berarti tidak terjadi heteroskedastisitas pada model regresi, sehingga model regresi layak dipakai untuk mengetahui agresivitas pajak berdasar masukan dari variabel independennya.

\section{Uji Multikolonearitas}

Uji Multikolonieritas bertujuan untuk menguji apakah pada model regresi ditemukan adanya korelasi antar variabel bebas (independen). Multikolinearitas dalam regresi dapat dilihat dari tolerance value dan variance inflation factor (VIF). Nilai cut off yang umum dipakai untuk 
menunjukkan ada tidaknya multikolinearitas nilai tolerance $>0,10$ atau sama dengan nilai VIF $<10$. Hasil uji multikolinearitas dilihat pada Tabel 7 berikut :

Tabel 7

Hasil Uji Multikolonearitas

Coefficients(a)

\begin{tabular}{cccc}
\hline \multirow{2}{*}{ Model } & \multicolumn{2}{c}{ Collinearity Statistics } \\
& Tolerance & VIF \\
\hline 1 & (Constant) & & \\
& Ukuran Perusahaan & 0,991 & 1,009 \\
CSR & 0,663 & 1,507 \\
& Capital Intensity & 0,733 & 1,364 \\
Leeverage & 0,796 & 1,257 \\
& Komisaris Independen & 0,789 & 1,268 \\
\hline
\end{tabular}

a. Dependent Variable: Agresivitas Pajak

Sumber : Data diolah, 2019

\section{Uji Koefisien Regresi}

Pengujian hipotesis pada penelitian ini menggunakan uji koefisien regresi untuk memperoleh gambaran mengenai pengaruh ukuran perusahaan, Corporate Social Responsibility, capital intensity, leverage dan komisaris independen terhadap agresivitas pajak penghasilan.

\section{Tabel 8}

Hasil Uji Koefisien Regresi

Coefficients(a)

\begin{tabular}{|c|c|c|c|c|c|c|c|c|}
\hline \multirow{2}{*}{ Model } & & \multicolumn{2}{|c|}{$\begin{array}{l}\text { Unstandardized } \\
\text { Coefficients }\end{array}$} & \multirow{2}{*}{$\begin{array}{c}\text { Standardized } \\
\text { Coefficients } \\
\text { Beta }\end{array}$} & \multirow[t]{2}{*}{$t$} & \multirow{2}{*}{ Sig. } & \multicolumn{2}{|c|}{$\begin{array}{l}\text { Collinearity } \\
\text { Statistics }\end{array}$} \\
\hline & & B & $\begin{array}{l}\text { Std. } \\
\text { Error }\end{array}$ & & & & Tolerance & VIF \\
\hline \multirow[t]{6}{*}{1} & (Constant) & $-45,230$ & 37,776 & & $-1,197$ & 0,247 & & \\
\hline & Ukuran Perusahaan & 0,000 & 0,000 & 0,288 & 1,883 & 0,076 & .991 & 1.009 \\
\hline & CSR & 165,299 & 67,085 & 0,461 & 2,464 & 0,024 & .663 & 1.507 \\
\hline & Capital Intensity & 4,204 & 0,942 & 0,794 & 4,464 & 0,000 & .733 & 1.364 \\
\hline & Leverage & $-30,658$ & 15,568 & $-0,336$ & $-1,969$ & 0,065 & .796 & 1.257 \\
\hline & Komisaris Independen & 45,620 & 48,398 & 0,162 & 0,943 & 0,358 & .789 & 1.268 \\
\hline
\end{tabular}

a. Dependent Variable: Agresivitas Pajak

Sumber : Data Diolah, 2019

Berdasarkan Tabel 8, maka dapat disusun persamaan regresinya:

$\mathrm{Y}=-45,230+0,000 \mathrm{X} 1+165,299 \mathrm{X} 2+4,204 \mathrm{X} 3-30,658 \mathrm{X} 4+45,620 \mathrm{X} 5+\mathrm{e}$

\section{Uji Kelayakan Model (Uji Statistik F)}

Uji F dilakukan untuk menguji apakah model regresi telah memenuhi uji kelayakan model. Hasil dari uji $\mathrm{F}$ dapat dlihat pada tabel berikut :

Tabel 9

Hasil Uji Kelayakan Model (Uji Statistik F)

$\operatorname{ANOVA}(\mathrm{b})$

\begin{tabular}{ccccccc}
\hline Model & & Sum of Squares & df & Mean Square & F & Sig. \\
\hline \multirow{2}{*}{1} & Regression & 10739,165 & 5 & 2147,833 & 5,025 & $0,005(\mathrm{a})$ \\
& Residual & 7694,393 & 18 & 427,466 & & \\
& Total & 18433,558 & 23 & & & \\
\hline
\end{tabular}

a. Predictors: (Constant), Komisaris Independen, Ukuran Perusahaan, Capital Intensity, Leverage, CSR

b. Dependent Variable: Agresivitas Pajak

Sumber : Data diolah, 2019

Uji t 
Uji t dalam penelitian ini dilakukan untuk menunjukkan seberapa jauh pengaruh satu variabel penjelas/independen secara individu dalam menerangkan variasi variabel dependen (Ghozali, 2018). Hasil uji T dapat dilihat pada Tabel berikut:

Tabel 10

Hasil Uji t

\begin{tabular}{|c|c|c|c|c|c|c|}
\hline \multirow[t]{2}{*}{ Model } & & \multicolumn{2}{|c|}{ Unstandardized Coefficients } & \multirow{2}{*}{$\begin{array}{c}\text { Standardized } \\
\text { Coefficients } \\
\text { Beta }\end{array}$} & \multirow[t]{2}{*}{$\mathrm{t}$} & \multirow{2}{*}{ Sig. } \\
\hline & & B & Std. Error & & & \\
\hline \multirow[t]{6}{*}{1} & (Constant) & $-45,230$ & 37,776 & & $-1,197$ & 0,247 \\
\hline & Ukuran Perusahaan & 0,000 & 0,000 & 0,288 & 1,883 & 0,076 \\
\hline & CSR & 165,299 & 67,085 & 0,461 & 2,464 & 0,024 \\
\hline & Capital Intensity & 4,204 & 0,942 & 0,794 & 4,464 & 0,000 \\
\hline & Leverage & $-30,658$ & 15,568 & $-0,336$ & $-1,969$ & 0,065 \\
\hline & Komisaris Independen & 45,620 & 48,398 & 0,162 & 0,943 & 0,358 \\
\hline
\end{tabular}

a. Dependent Variable: Abs_RES

Sumber : Data diolah, 2019

\section{Uji Koefisien Determinan (R2)}

Koefisien determinasi (R2) pada regresi linear sering diartikan sebagai seberapa besar kemampuan semua variabel independen dalam menjelaskan varians dari variabel dependennya. Secara sederhana koefisien determinasi dihitung dengan mengkuadratkan Koefisien Korelasi (R). Hasil uji koefisien determinasi (R2) dapat dilihat pada Tabel berikut :

Table 11

Hasil Uji Koefisien Determinasi (R2) Model Summary(b)

\begin{tabular}{cccccc}
\hline Model & R & R Square & Adjusted R Square & Std. Error of the Estimate & Durbin-Watson \\
\hline 1 & $0,763(\mathrm{a})$ & 0,583 & 0,467 & 20,675258 & 2,108 \\
\hline
\end{tabular}

a. Predictors: (Constant), Komisaris Independen, Ukuran Perusahaan, Capital Intensity, Leverage, CSR

b. Dependent Variable: Agresivitas Pajak Sumber : Data diolah, 2019

\section{Pembahasan}

\section{Pengaruh Ukuran Perusahaan terhadap Agresivitas Pajak Penghasilan}

Berdasarkan hasil uji $\mathrm{t}$ diperoleh nilai signifikansi sebesar $0,076>0,05$ serta nilai koefisien regresinya adalah 0,000 . Hal tersebut berarti bahwa variabel ukuran perusahaan tidak berpengaruh positif terhadap agresivitas pajak penghasilan.

\section{Pengaruh Corporate Social Responsibility (CSR) terhadap Agresivitas Pajak Penghasilan}

Corporate Social Responsibility (CSR) terhadap agresivitas pajak penghasilan. Berdasarkan hasil uji t diperoleh nilai signifikansi sebesar 0,024<0,05 dan nilai koefisien regresi sebesar 165,299, sehingga variabel Corporate Social Responsibility (CSR) berpengaruh positif terhadap agresivitas pajak penghasilan. Dapat diartikan bahwa apabila nilai Corporate Social Responsibility (CSR) perusahaan tinggi, maka kemungkinan perusahaan melakukan tindakan agresivitas pajak penghasilan juga tinggi.

Pengaruh Capital Intensity terhadap Agresivitas Pajak Penghasilan

Berdasarkan hasil uji t diperoleh nilai signifikansi sebesar $0,000<0,05$ dan nilai koefisien regresi sebesar 4,204, yang artinya bahwa variabel capital intensity berpengaruh positif terhadap agresivitas pajak penghasilan. Dapat diartikan bahwa apabila nilai suatu capital intensity atau kemampuan perusahaan berkorban mengeluarkan dana untuk aktivitas operasi dan pendanaan aktiva guna memperoleh keuntungan perusahaan rendah, maka kemungkinan perusahaan melakukan tindakan agresivitas pajak penghasilan juga rendah, begitu juga sebaliknya.

Pengaruh Leverage terhadap Agresivitas Pajak Penghasilan 
Berdasarkan hasil uji t diperoleh nilai signifikansi sebesar 0,065 >0,05 dan nilai koefisien regresi sebesar $-30,658$, yang artinya variabel leverage tidak berpengaruh negatif terhadap agresivitas pajak penghasilan. Berdasarkan hasil tersebut maka dapat disimpulkan bahwa besar kecilnya nilai leverage tidak mempengaruhi suatu perusahaan akan melakukan tindakan agresivitas pajak penghasilan.

\section{Pengaruh Komisaris Independen terhadap Agresivitas Pajak Penghasilan}

Berdasarkan hasil uji $\mathrm{t}$ diperoleh nilai signifikansi sebesar $0,358>0,05$ dan nilai koefisien regresi sebesar 45,620 yang artinya bahwa variabel komisaris independen tidak berpengaruh positif terhadap agresivitas pajak penghasilan. Sehingga, perusahaan yang memiliki komisaris independen yang baik ataupun buruk maka tidak menjadi pengaruh perusahaan tersebut juga melakukan tindakan agresivitas pajak.

\section{SIMPULAN}

Penelitian ini bertujuan untuk mengetahui apakah ada pengaruh ukuran perusahaan, Corporate Social Responsibility (CSR), capital intensity, leverage dan komisaris independen terhadap agresivitas pajak penghasilan pada perusahaan industri konsumsi di Bursa Efek Indonesia (BEI) selama tahun 2015-2017. Selama analisis data yang dilakukan, makan dapat disimpulkan bahwa Ukuran perusahaan tidak berpengaruh positif terhadap agresivitas pajak penghasilan wajib pajak badan perusahaan industri konsumsi di Bursa Efek Indonesia (BEI). Corporate Social Responsibility (CSR) berpengaruh positif terhadap agresivitas pajak penghasilan wajib pajak badan perusahaan industri konsumsi di Bursa Efek Indonesia (BEI). Capital intensity berpengaruh positif terhadap agresivitas pajak penghasilan wajib pajak badan perusahaan industri konsumsi di Bursa Efek Indonesia (BEI). Leverage tidak berpengaruh negatif terhadap agresivitas pajak penghasilan wajib pajak badan perusahaan industri konsumsi di Bursa Efek Indonesia (BEI). Komisaris independen tidak berpengaruh terhadap agresivitas pajak penghasilan wajib pajak badan perusahaan industri konsumsi di Bursa Efek Indonesia (BEI).

Berdasarkan kesimpulan tersebut maka adapun saran-saran yang akan diberikan adalah Bagi perusahaan manufaktur khususnya industri konsumsi sebaiknya semua perusahaan membuat laporan keberlanjutan perusahaan (sustainability reporting) untuk memudahkan pengungkapan tanggung jawab sosial. Bagi peneliti selanjutnya yang berminat melakukan penelitian dengan topik yang sama disarankan untuk menambah variabel lain seperti kepemilikan keluarga, manajemen laba dan lainlain serta menggunakan periode pengamatan yang lebih lama sehingga diharapkan hasil penelitian akan menjadi semakin baik. Bagi manajemen perusahaan sebaiknya untuk lebih memperhatikan setiap tindakan yang akan dilakukan beserta risiko yang akan ditanggung dari setiap keputusan yang dibuat sesuai dengan peraturan dan perundang-undangan perpajakan yang berlaku dilihat dari variabel Corporate Social Responsibility (CSR) dan capital intensity yang memiliki pengaruh positif mengenai tindakan agresivitas pajak yang dilakukan perusahaan.

\section{DAFTAR PUSTAKA}

Ayem, S., \& Setyadi, A. (2019). Pengaruh Profitabilitas, Ukuran Perusahaan, Komite Audit Dan Capital IntensityTerhadap Agresivitas Pajak (Studi Pada Perusahaan Perbankan Yang Terdaftar di BEI Periode Tahun 2013- 2017). Jurnal Akuntansi Pajak Dewantara, 1(2), 228-241. Retrieved from https://doi.org/10.24964/japd.v1i2.905

Cahyono, D. D., Andini, R., \& Raharjo, K. (2016). Pengaruh Komite Audit, Kepemilikan Institusional, Dewan Komisaris, Ukuran Perusahaan (Size), Leverage (Der) Dan Profitabilitas (Roa) Terhadap Tindakan Penghindaran Pajak (Tax Avoidance) Pada Perusahaan Perbankan Yang Listing Bei Periode Tahun 2011 - 2013. Jurnal Ilmiah Mahasiswa S1 Akuntansi Universitas Pandanaran, 2(2). Retrieved from https://jurnal.unpand.ac.id/index.php/AKS/article/view/462

Dwiyanti, I. A. I., \& Jati, I. K. (2019). Pengaruh Profitabilitas, Capital Intensity, dan Inventory Intensity pada Penghindaran Pajak. E-Jurnal Akuntansi Universitas Udayana, 27(3), 2293-2321. Retrieved from https://doi.org/10.24843/EJA.2019.v27.i03.p24 
Fadli, I., Ratnawati, V., \& Kurnia, P. (2016). Pengaruh Likuiditas, Leverage, Komisaris Independen, Manajemen Laba,Dan Kepemilikan Institusional Terhadap Agresivitas Pajak Perusahaan (Studi pada perusahaan manufaktur yang terdaftar di Bursa Efek Indonesia periode 2011-2013). Jurnal Online Mahasiswa (JOM) Fakultas Ekonomi Universitas Riau, 3(1). Retrieved from https://jom.unri.ac.id/ index.php/JOMFEKON/article/view/11451

Ghozali, I. (2016). Aplikasi Analisis Multivariate dengan Program IBM 23 SPSS. Semarang: BPFE Universitas Diponogoro.

Ghozali, I. (2018). Aplikasi Analisis Multivariate dengan Program IBM SPSS 25 Update PLS Regresi. Semarang: Badan Penerbit Universitas Diponegoro.

Hidayati, N. D., \& Saifi, M. (2019). Corporate Social Responsibility (Csr) Dan Kinerja Keuangan Perusahaan (Studi Pada Perusahaan Semen Yang Terdaftar Di Bursa Efek Indonesia Tahun 2013-2017). Jurnal Administrasi Bisnis Universitas Brawijaya, 72(2), 100-109. Retrieved from http:// administrasibisnis.studentjournal.ub.ac.id/index.php/jab/article/view/2870

Kasmir. (2016). A nalisis Laporan Keuangan. Jakarta: PT Raja Grafindo Persada.

Mustika, Ratnawati, V., \& Silfi, A. (2017). Pengaruh Corporate Social Responsibility, Ukuran Perusahaan, Profitabilitas, Leverage, Capital Intensity dan Kepemilikan Keluarga terhadap Agresivitas Pajak (Studi Empiris pada Perusahaan Pertambangan dan Pertanian yang Terdaftar di Bursa Efek Indonesia P. Jurnal Online Mahasiswa Fakultas Ekonomi Universitas Riau, 4(1), 1886-1900. Retrieved from https://jom.unri.ac.id/index.php/JOMFEKON/article/view/13315

Nugraha, N. B., \& Meiranto, W. (2015). Pengaruh Corporate Social Responsibility, Ukuran Perusahaan, Profitabilitas, Leveragedan Capital Intensityterhadap Agresivitas Pajak (Studi Empiris pada Perusahaan Non Keuanganyang Terdaftar di Bursa Efek Indonesia 2012-2013). DIPONEGORO JOURNAL OF ACCOUNTING, 4(4), 1-14. Retrieved from https://media.neliti.com/media/ publications/253478-pengaruh-corporate-social-responsibility-b8c8ea8d.pdf

Rina, N. F. (2016). Pengaruh Pengungkapan Corporate Social Responsibili (CSR), Ukuran Perusahaan (Size), Leverage, Return On Asset (Roa) Dan Kepemilikan Keluarga Terhadap Agresivitas Pajak (Studi pada Perusahaan Manufaktur yang Terdaftar di Bursa Efek Indonesia Tahun 2013 -. Jurusan Akuntansi Syariah Fakultas Ekonomi Bisnis Dan Islam Institut Agama Islam Negeri Surakarta. Retrieved from http://eprints.iain-surakarta.ac.id/260/1/18. Nona Fajar Rina.pdf

Rudangga, I. G. N. G., \& Sudiarta, G. M. (2016). Pengaruh Ukuran Perusahaan, Leverage, dan Profitabilitas terhadap Nilai Perusahaan. E-Jurnal Manajemen Universitas Udayana, 5(7), 4394-4422. Retrieved from https://www.neliti.com/id/publications/243363/pengaruh-ukuran-perusahaan-leverage-danprofitabilitas-terhadap-nilai-perusahaan

Suandy, E. (2004). Perencanaan Pajak. Jakarta: Salemba Empat.

Untung, B. H. (2009). Corporate Social responsibility. Cetakan Kedua. Jakarta: Sinar Grafika. 